\title{
TRADISI LISAN BHANTI-BHANTI SEBAGAI MEDIA KOMUNIKASI KULTURAL DALAM MASYARAKAT WAKATOBI
}

\author{
Sumiman Udu*
}

\begin{abstract}
Bhanti-bhanti is a folksong that grown and developed in Wakatobi society. As a folksong, the performancing of bhanti-bhanti oral tradition can be used as an effective cultural media of communication, especially in presenting their messages, both from the singer as well as the listeners regardless of their age and social status. The performancing of bhanti-bhanti is cultural media of communication in Wakatobi, that used by local government, sara (traditional institution), as well as local people of Wakatobi. All elements can express their thoughts and feelings about culture, history, custom, human relation with environment as well as God. They also can used bhanti-bhanti to express their toughts and feelings to someone, village, or another social issues. By using bhantibhanti, the listeners can not be offended by the criticism because its criticism conveyed in subtle language and full of jokes.
\end{abstract}

Keywords: bhanti-bhanti, communication media, community, cultural, Wakatobi

\begin{abstract}
ABSTRAK
Tradisi lisan Bhanti-bhanti merupakan nyanyian rakyat yang selama ini tumbuh dan berkembang dalam masyarakat Wakatobi. Sebagai nyanyian rakyat, pementasan tradisi lisan bhanti-bhanti merupakan ruang komunikasi kultural yang efektif, terutama dalam menyampaikan berbagai pesan, baik dari pelantun maupun dari pendengar, tanpa membedakan umur dan status sosial. Pementasan tradisi lisan bhanti-bhanti merupakan media komunikasi kultural masyarakat Wakatobi, baik yang berasal dari pemerintah daerah, sara (lembaga tradisional), maupun dari masyarakat biasa. Semua yang hadir dalam pementasan tersebut memiliki ruang untuk menyampaikan berbagai hal yang menyangkut berbagai nilai budaya, sejarah, adat istiadat, hubungan manusia dengan lingkungan, yang berhubungan dengan Tuhannya. Mereka juga bebas mengungkapkan pikiran, perasaannya terhadap seseorang, kampung, ataupun masalah sosial lainnya, dan pendengar tidak bisa tersinggung karena kritik itu disampaikan dengan bahasa halus dan penuh dengan canda.
\end{abstract}

Kata kunci: bhanti-bhanti, kultural, masyarakat, media komunikasi, Wakatobi

* Fakultas Keguruan dan Ilmu Pendidikan, Universitas Haluoleo Kendari, Sulawesi Tenggara 


\section{PENGANTAR}

Indonesia memiliki kekayaan tradisi lisan yang tersebar di berbagai daerah di Nusantara (Danandjaja, 1994:9-12). Tradisi lisan sebagai kekayaan budaya bangsa merupakan salah satu bentuk ekspresi kebudayaan daerah yang berharga, sebab tidak hanya menyimpan nilai-nilai budaya dari masyarakat tradisional, tetapi juga dapat menjadi akar budaya dari suatu masyarakat baru. Mursal Esten (1999:105) mengatakan bahwa sastra lisan dapat menjadi sumber bagi suatu penciptaan budaya baru di dalam masyarakat modern. Moradewun Adejunmobi (2011:3) mengatakan bahwa tradisi lisan menjadi sumber inspirasi bagi penciptaan musik dan film yang diproduksi di Afrika dan India. Berangkat dari pemikiran di atas, maka tradisi lisan diharapkan dapat menyumbangkan kontribusi dalam perkembangan industri kreatif di tengah masyarakat Indonesia dewasa ini.

Wakatobi merupakan salah satu bharata yang ada dalam wilayah Kesultanan Buton yang dahulu dikenal dengan nama bharata Kaedupa (Udu, 2010:19). Dalam bahasa Wolio kata bharata berarti perahu yang bercadik ganda dengan empat simpul penguat yang diindentifikasikan pada dua kerajaan di bagian barat, yaitu Kerajaan Wuna dan Kerajaan Tiworo, dan dua kerajaan di bagian timur, yaitu Kerajaan Kaedupa dan Kerajaan Kulisusu (Zuhdi, 2012:xix). Beberapa kerajaan tersebut kemudian bergabung dalam Kerajaan Buton dengan tetap memiliki otonom dalam bidang kebudayaan sehingga keempatnya memiliki budaya yang berbeda satu dengan yang lainnya.

Bharata Kaedupa secara geografis merupakan daerah Kepuluan Tukang Besi yang ada di sebelah timur Pulau Buton. Pada tahun 2003, daerah ini telah dimekarkan menjadi Kabupaten Wakatobi melalui Undang-Undang Nomor 19 tahun 2003 tentang Pembentukan Kabupaten Bombana, Wakatobi, dan Konawe Utara di Provinsi Sulawesi Tenggara.
Sejak dahulu masyarakat Wakatobi telah memiliki keunikan budaya jika dibandingkan dengan budaya yang ada pada bharata-bharata lainya di dalam Kesultanan Buton dan daerah lainnya di Nusantara. Hal ini disebabkan masyarakat Wakatobi berasal dari para pendatang yang kemudian bermukim di daerah ini (bdk. Schoorl, 2003:121). Hal ini dibuktikan dengan adanya beberapa subetnik yang ada di Wakatobi, yaitu subetnik Wanse, Mandati, Kapota, Kaedupa, Tomia, dan Binongko. Di samping itu, ada dua subetnik yang juga tidak dapat dipisahkan dari masyarakat Wakatobi, yakni subetnik Bajo dan subetnik Cia-Cia.

Keragaman masyarakat Wakatobi telah menjadikan Wakatobi sebagai salah satu daerah yang memiliki berbagai jenis tradisi yang tumbuh dan berkembang di berbagai subetnik yang ada. Namun, di tengah keragaman tersebut, tradisi bhanti-bhanti dapat menyatukan keragaman budaya dan masyarakat Wakatobi. Pementasan tradisi lisan bhanti-bhanti menjadi salah satu media komunikasi kultural yang ada di setiap etnis yang ada di Wakatobi. Melalui pementasan bhanti-bhanti, masyarakat Wakatobi mampu menyampaikan berbagai pikiran dan perasaannya, baik menyangkut pikiran dan perasaan yang menyangkut pribadi, maupun pikiran dan perasaan yang menyangkut masalah sosial yang terjadi di dalam kehidupan sosial mereka.

Keragaman subetnik dan budaya tersebut menjadi potensi budaya yang dapat dimanfaatkan oleh masyarakat Wakatobi dalam pembangunannya dewasa ini. Namun, keragaman itu juga memiliki potensi untuk menjadi kendala dalam pembangunan masyarakat Wakatobi jika potensi itu tidak dikelola dengan baik. Setiap subetnik memiliki kecenderungan untuk melakukan dominasi atas subetnik yang lainnya. Dengan demikian, untuk mempersatukan berbagai kalangan tersebut, dibutuhkan satu media komunikasi yang mampu menyatukan berbagai perbedaan yang ada. Salah satu media komunikasi kultural yang dapat digunakan untuk menyatukan 
berbagai ide dan gagasan yang ada dalam masyarakat Wakatobi adalah melalui pementasan tradisi bhanti-bhanti Wakatobi.

Dalam bahasa Wakatobi, kata bhantibhanti memiliki dua pengertian, yaitu (1) bhantibhanti yang berarti sindiran dan (2) bhantibhanti yang berarti nyanyian rakyat (Wawancara dengan La Ode Kamaluddin tanggal 2 Februari 2011). Sebagai nyanyian rakyat, tradisi itu selama ini tumbuh dan berkembang dalam masyarakat Wakatobi (Udu, 2010:19-20). Nsaha (1987/1988:235) mengatakan bahwa kabhanti atau bhanti-bhanti merupakan nyanyian rakyat yang disampaikan dalam bahasa halus sehingga menyentuh sampai di hati. Taalami (2008:59) mengatakan bahwa kata bhanti dalam bahasa Wakatobi berarti dua pengertian, yaitu sebagai "sindiran halus" dan sebagai salah satu jenis lagu yang berisi ungkapan perasaan (cinta kasih, sedih, kegembiraan, dan kerinduan), juga nasihat.

Beberapa pengertian tentang bhanti-bhanti di atas dikuatkan oleh Anceaux (1984:51) yang mengartikan kabhanti atau bhanti-bhanti sebagai puisi, sajak, atau nyanyian. La Niampe (1998:54) mengatakan bahwa secara etimologis kabhanti merupakan kata jadian dalam bahasa Wolio yang terdiri dari morfem ka- dan kata dasar bhanti. Morfem terikat ka- berfungsi sebagai pembentuk kata benda atau ihwal benda, sedangkan morfem bebas banti mengandung pengertian puisi. Jadi, kabhanti atau bhanti-bhanti berarti ihwal yang dikenal sebagai salah satu kesusastraan Buton yang berbentuk puisi (Udu, 2006:12). Dengan demikian, kata bhanti dalam bahasa Wakatobi berarti (1) sindiran halus (menggunakan kata metafor) dan (2) nyanyian rakyat.

Sebagai tradisi lisan, tradisi bhanti-bhanti mempunyai pementasan yang melibatkan berbagai sarana untuk mendukung pementasan tersebut. Pascal Boyer (1990) melihat tradisi lisan sebagai objek kajian antropologi yang penting untuk diungkap dalam memahami sebuah kebudayaan, sistem sosial, psikologi, maupun aspek struktur suatu masyarakat. Finnegan (1978:7) mengatakan bahwa pementasan tradisi lisan melibatkan beberapa hal, yaitu pelantun, penonton, dan sarana prasarana yang mendukung pementasan. Di samping itu, sebuah pementasan tidak akan terlepas dari aspek sosial budaya, politik dan ekonomi dari masyarakat pendukungnya (Finnegan, 1992:122). Fine (1984:58) mengatakan bahwa ada tiga fokus yang perlu diperhatikan dalam kajian pementasan sastra lisan, yaitu (1) pementasan tradisi lisan sebagai model estetika dan gaya komunikasi, 2) pementasan tradisi lisan berhubungan dengan peristiwa tertentu, dan 3) pementasan tradisi lisan sebagai peristiwa budaya khusus dan varibel dari studi lintas-budaya.

Dengan merujuk pada pemikiran Fine (1984) di atas, pementasan tradisi lisan bhanti-bhanti dapat dijadikan sebagai model estetika dan gaya komunikasi kultural dalam masyarakat Wakatobi. Melalui pementasan bhanti-bhanti, masyarakat Wakatobi dapat mengomunikasikan berbagai hal yang menyangkut kehidupan mereka, antara lain (1) dapat merefleksi maupun memproyeksi tentang kehidupan mereka, (2) dapat menyampaikan berbagai pesan tanpa membedakan umur, jenis kelamin dan status sosial yang dilakukan oleh pelantun dan pendengar, dan (3) dapat mengemukakan pikiran dan perasaannya baik yang menyangkut aspek pribadi maupun yang menyangkut aspek sosial mereka dengan bebas, tanpa takut jangan sampai tersinggung.

Sesuai dengan tujuan penelitian dan karakteristik masalah yang ada, penggunaan paradigma etnografi dibutuhkan untuk menjelaskan berbagai konteks sosial budaya yang ada dalam pementasan tradisi lisan bhanti-bhanti. Dengan demikian, peneliti berfungsi sebagai instrumen kunci dalam proses pengumpulan data. Dalam pengumpulan data, peneliti melakukan perekaman, pengamatan secara mendalam, serta melakukan pencatatan lapangan secara cermat tentang konteks dan pementasan tradisi bhantibhanti. Di samping itu, peneliti juga melakukan wawancara mendalam dengan para pelantun dan para tokoh masyarakat untuk memperoleh penjelasan mengenai berbagai konteks yang mendukung pementasan tradisi bhanti-bhanti Wakatobi. 
Lokasi penelitian ini adalah para pelantun dan penonton tradisi bhanti-bhanti yang ada dalam masyarakat Wakatobi. Para pelantun dan penonton tradisi bhanti-bhanti memiliki tingat variasi yang tinggi karena masyarakat Wakatobi adalah masyarakat heterogen yang terdiri dari subetnik Wanse, Mandati, Kapota, Liya, Kaledupa, Tomia, Binongko, Cia-Cia, dan etnik Bajo.

Subjek penelitian ini adalah para pelantun dan penonton tradisi bhanti-bhanti yang ada di Wakatobi. Oleh karena itu, sumber data penelitian ini adalah para pelantun, penonton, dan tokoh-tokoh masyarakat Wakatobi yang memahami budaya Wakatobi. Dengan demikian, data penelitian ini berupa hasil rekaman pementasan tradisi bhanti-bhanti serta berbagai hasil wawancara yang didapatkan dari pelatun, penonton dan tokoh-tokoh yang ada dalam masyarakat Wakatobi.

Pengumpulan data penelitian ini dilakukan dengan metode etnografi melalui teknik (1) partisipasi, (2) observasi, (3) wawancara, dan (4) rekonstruksi data intuitif dan intropeksi. Analisis data penelitian ini dilakukan dengan prosedur (1) penelaahan dan penyeleksian data, (2) pengidentifikasian dan pengunitan data, (3) pengategorian atau penggolongan data, dan (4) penafsiran dan penjelasan makna data.

Temuan penelitian ini menunjukkan bahwa ada beberapa elemen masyarakat yang menggunakan pementasan tradisi bhanti-bhanti sebagai komunikasi kultural dalam masyarakat Wakatobi. Dikatakan oleh Arif bahwa "manusia berkomunikasi dalam tataran komunikasi kultural, mereka menggunakan bahasa dan istilah yang biasa dipakai dalam masyarakat. Komunikasi kultural itu meliputi komunikasi politik, ekonomi perdagangan, hukum, dan masalah pribadi ataupun keluarga" (jatengonline.com, diakses tanggal 24 Januari 2014). Dengan demikian, pementasan tradisi bhanti-bhanti Wakatobi merupakan bentuk komunikasi yang menggunakan bahasa dan istilah yang digunakan oleh masyarakat Wakatobi. Mereka terikat oleh norma-norma, nilai kultural yang ada di dalam masyarakat Wakatobi.
Dikatakan oleh Suyitno (2006:263-264) bahwa dalam berkomunikasi masyarakat diikat oleh nilainilai, norma-norma yang mereka patuhi bersama oleh kelompok masyarakat tersebut sehingga komunikasi kultural adalah komunikasi yang menggunakan bahasa dan istilah yang ada dalam suatu masyarakat yang tetap diikat oleh nilai-nilai dan norma-norma yang ada dalam masyarakat tersebut. Oleh karena itu, pementasan tradisi lisan bhanti-bhanti merupakan media komunikasi kultural masyarakat Wakatobi yang memuat nilai-nilai, norma-norma yang tetap dipatuhi oleh masyarakat Wakatobi.

Partisipan yang ada dalam pementasan tradisi bhanti-bhanti Wakatobi meliputi (1) komunikasi kultural yang terjadi antara ibu dan anakanaknya, (2) komunikasi kultural yang terjadi antara muda-mudi, (3) komunikasi kultural antara rakyat dan pemerintahnya, dan (4) komunikasi kultural yang terjadi antarkampung di Wakatobi. Beberapa elemen masyarakat Wakatobi itu menggunakan pementasan tradisi lisan sebagai media komunikasi dalam menyampaikan berbagai pikiran dan perasaan mereka.

\section{BHANTI-BHANTI SEBAGAI MEDIA KOMUNIKASI ANTARA ANAK DAN ORANG TUA}

Penggunaan tradisi lisan bhanti-bhanti dalam masyarakat Wakatobi sebagai media komunikasi kutural telah dilakukan masyarakat Wakatobi dalam bentuk dialog yang dilakukan oleh seorang anak kepada orang tua. Harapan dan impian anak kepada orang tua dapat diungkapkan dalam bentuk pementasan tradisi lisan bhanti-bhanti Wakatobi. Jika dalam kondisi biasa seorang anak susah merefleksikan kecintaan dan harapannya pada ibu mereka, dalam pementasan bhantibhanti semua itu dapat dikomunikasikan dengan mudah. Demikian juga sebaliknya, seorang ibu yang memiliki impian pada anak-anaknya akan disampaikan dalam bentuk tradisi lisan bhantibhanti. Sejak dahulu ibu-ibu di Wakatobi telah memberikan impian kepada anak-anaknya melalui bhanti-bhanti sebagai pengantar tidur. Mereka 
telah menanamkan pentingnya pendidikan kepada anaknya. Dalam teks bhanti-bhanti pengatar tidur, dijelaskan bahwa /mou ane na mbena-mbenal 'Walaupun ada permata' /kumeta'o la nsumikolal 'aku akan menunggu yang berpendidikan'. Hal ini sama dengan pemikiran Fakih (2003:165), yaitu dengan pergaulan dan pengetahuan yang memadai, seseorang akan keluar dari kungkungan kemiskinan dan ketakberdayaan. Albom Mitch (2006:81) mengatakan bahwa satu-satunya jalan untuk keluar dari kemiskinan adalah pendidikan. Ini menunjukkan bahwa melalui teks-teks bhantibhanti seorang ibu di Wakatobi telah berpikir untuk keluar dari kemiskinan yang mendera kehidupannya. Mereka menyadari bahwa yang membuat mereka tidak berdaya adalah karena mereka bodoh secara kultural. Oleh karena itu, pementasan bhanti-bhanti merupakan media komunikasi kultural yang sejak dini mengajarkan pentingnya pendidikan bagi anak-anak Wakatobi. Seorang ibu dapat mengomunikasikan harapan dan impiannya kepada anak-anaknya bahwa ia sangat mengimpikan seorang yang berpendidikan. Sehubungan dengan pilihan ibu untuk memilih yang berpendidikan dibandingkan dengan orang kaya yang ada dalam teks-teks bhanti-bhanti tersebut, sejalan dengan pernyataan La Be'e (51) bahwa "saya rela menderita bekerja sebagai seorang tukang pikul asal anak-anakku dapat kuliah dan menjadi sarjana" (wawancara dengan La Be'e pada tanggal 12 Januari 2012).

Dalam suatu pementasan yang dilakukan oleh La Ode Kamaluddin (sang Maestro kabhanti atau bhanti-bhanti Wakatobi) pada tanggal 16 Oktober 2012 di rumah H. La Wole di kelurahan Wanci, dipresentasikan perasaan anak-anak kepada ibu mereka yang sudah tua. Ia mengungkapkan harapan dan cinta anak-anak kepada ibunya melalui teks berikut. $\begin{aligned} & \text { Ara te dhi angka na Kalau kematian itu dapat } \\ & \text { mate }\end{aligned}$
dilarang

Te wa ina bhara Maka ibu janganlah nomate meninggal

Setelah mendengarkan teks tersebut, salah seorang penonton mengatakan bahwa "ternyata bhanti-bhanti itu kalau kita hayati, dapat membuat kita menyadari makna dari kehidupan ini, kasih sayang ibu dapat kita hargai, serta kita dapat menghargai kemanusiaan, menghargai ibu yang telah melahirkan kita (wawancara tanggal 19 Februari 2012 dengan Musaidin). Ia juga menambahkan bahwa kalau kita mendengarkan bhanti-bhanti, kita akan menyadari betapa pentingnya pengabdian seorang anak kepada ibunya. Ini menunjukkan bahwa tradisi lisan bhanti-bhanti mampu mengomunikasikan pikiran dan perasaan anak-anak kepada ibunya dan juga seorang ibu kepada anak-anaknya yang tentunya akan susah diungkapkan dalam komunikasi biasa. Selain itu, seorang ibu juga dapat mengetahui dan memahami cinta dan harapan dari anak-anak yang mencintainya. Dalam teks yang lain, $\mathrm{La}$ Ode Kamaluddin melantunkan teks bhanti-bhanti sebagai berikut.

$$
\begin{array}{lrl}
\begin{array}{l}
\text { Mate wa ama } \\
\text { ngkokilua }
\end{array} & \begin{array}{l}
\text { Kematian ayah membuat } \\
\text { kami yatim }
\end{array} \\
\begin{array}{l}
\text { Mate wa ina } \\
\text { ngkomantale }
\end{array} & \begin{array}{l}
\text { Kematian ibu membuat } \\
\text { kami tercerai berai }
\end{array}
\end{array}
$$

Teks di atas mengomunikasikan kondisi psikologis penonton yang sudah lama ditinggal ayah mereka. Namun, walaupun sudah lama ditinggal ayah, mereka masih tetap hidup rukun karena masih memiliki kasih sayang seorang ibu yang tetap mempersatukan mereka. Mereka hidup miskin, tetapi kasih sayang ibu membuat mereka tetap tegar dalam menjalani kehidupan. Teks di atas juga dapat mengomunikasikan kekhawatiran anak-anak atas kematian ibunya kelak, karena kematian ibu akan berdampak pada keretakan kehidupan keluarga, mereka menganggap bahwa ibulah yang menyatukan mereka dengan cinta.

Seorang pelantun bhanti-bhanti mampu mewakili anak-anak yang berada di dekat ibunya yang sudah tua dan sakit-sakitan. Pengalaman mereka atas kematian ayah serta kesadaran mereka akan keberadaan ibu yang sudah mulai tua dapat direpresentasikan dalam bentuk teksteks bhanti-bhanti di atas. Teks bhanti-bhanti di atas menggambarkan pengalaman masyarakat Wakatobi yang biasanya akan bercerai-berai 
ketika ibu, tempat mereka menggantungkan cinta dan kasih sayang itu telah tiada. Kerinduan hanya akan mengisi kekosongan hati mereka, sementara untuk bersua dengan keluarga hampir waktunya telah tersita oleh kesibukan yang semakin padat. Ibulah yang mengikat keluarga dalam masyarakat Wakatobi.

Dalam konteks yang lain, pementasan tradisi lisan bhanti-bhanti sebagai pengantar tidur yang dipentaskan oleh Wa Yai (63) dapat menanamkan berbagai nilai kehidupan kepada anaknya. Salah satu yang mereka tanamkan adalah mengenai persoalan jodoh yang merupakan hak orang tua. Dalam salah satu teks bhanti-bhanti ia mengatakan bahwa /Te buri paka nteiguru/ 'jodoh tidak dapat diajari', /nolaha-laha ngkaramano/ 'ia akan datang dengan sendirinya'. Pandangan ini akan berdampak pada pengalaman si anak sampai ia dewasa, dan ketika dijodohkan, ia akan menurut saja. Namun, ketika anak-anak Wakatobi sudah mulai mengikuti pendidikan, seorang anak akan menjawab bhanti-bhanti tersebut dengan bhanti bahwa le wa ina kunto'ogemo/ 'ibu aku sudah besar' /kunumangkamo te larosu/ 'aku akan mengikuti hatiku'. Dialog yang terbangun dalam konteks pementasan bhanti-bhanti tersebut dapat membangun dialog dalam proses penentuan jodoh gadis-gadis di Wakatobi. Melalui dialog yang dibangun melalui teks-teks bhanti-bhanti seperti ini membuat keputusan tentang jodoh sudah mulai didialogkan sehingga gadis-gadis sudah dapat menentukan jodohnya sendiri. Yadin mengatakan bahwa "melalui teks bhantibhanti seperti di atas, saya dapat keluar dari kungkungan perjodohan keluarga besarku. Suatu waktu saya melantunkan teks itu di hadapan ibuku sehingga ia memahami keinginanku untuk mencintai perempuan lain yang bukan pilihannya (Wawancara dengan Himayatuddin/La Yadin pada tanggal 12 September 2012). Dengan demikian, berbagai masalah dalam kehidupan keluarga di dalam masyarakat Wakatobi yang ketika dikomunikasikan melalui teks-teks bhantibhanti akan mudah dan tidak membuat pihak lain tersinggung, termasuk dalam soal pemilihan jodoh untuk anak-anak mereka.
Konteks pementasan bhanti-bhanti yang dilakukan sebagai pengantar tidur yang dinyanyikan oleh Wa Ina Nii (70) dapat menjadi ruang refleksi atas dinamika kehidupan masyarakat Wakatobi. Susahnya kehidupan di Wakatobi direfleksikan dalam teks bhanti-bhanti berikut.

$\begin{array}{ll}\text { Wa ina bhara } & \text { Ibu jangan kau gusar } \\ \text { nusambira } & \\ \text { Ane kene Buru ngkene } & \text { Masih ada Buru dan } \\ \text { Ambo } & \text { Ambon }\end{array}$

Bait di atas menunjukkan bentuk komunikasi yang dilakukan oleh seorang ibu kepada anaknya mengenai kekhawatirannya pada masa depan kehidupan anaknya yang tidak pasti di Wakatobi. Maka, seorang ibu masih memberikan harapan baru kepada anaknya bahwa masih ada pulau Buru dan Ambon sebagai alternatif. Melihat hal itu, si aku lirik masih memiliki impian mengenai masa depan yang lebih baik untuk anaknya di masa depan. Si aku lirik mengatakan bahwa kalau tidak ada jodoh atau rezeki di Wakatobi, maka anaknya dapat mencari di pulau Buru dan Ambon. Ini menunjukkan bahwa melalui tradisi lisan bhanti-bhanti, ibu-ibu di Wakatobi telah menanamkan impian di luar pulau Wakatobi. Tidak mengherankan kalau masyarakat Wakatobi telah melakukan diaspora ke berbagai daerah di Nusantara.

Sejak dahulu masyarakat Wakatobi telah melakukan diaspora ke wilayah kepulauan Maluku, termasuk Pulau Buru dan Ambon. Kebanyakan mereka berangkat bersama keluarga untuk mencari pekerjaan atau membentuk pemukiman baru di sana. Beberapa perkampungan masyarakat Wakatobi di pulau Buru adalah Nalibesi, Namlea, Batulusi, dan beberapa daerah lainnya. Sementara itu, di Ambon, orangorang Wakatobi banyak menghuni beberapa tempat, seperti daerah Pasar Mahardika, Tolehu, Werinama, dan beberapa daerah lainnya di kepulauan Maluku dan bahkan sampai Papua (lihat Donohue, 1995:5-6; Rabani, 1997:27). Hal yang sama juga dikatakan oleh Schoorl (2001:108) bahwa masyarakat Wakatobi 
sudah terbiasa dalam melakukan pelayaran ke berbagai pulau di Nusantara. Hamid (2010:212) mengungkapkan kebiasaan orang Wakatobi-Buton dalam melakukan pelayaran untuk berdagang ke kepulaun Maluku dan Papua.

Dengan demikian, pementasan tradisi lisan bhanti-bhanti dapat menjadi media komunikasi kultural yang mampu menjembatani perbedaan pemikiran antara anak dan orang tua mereka. Melalui pementasan tradisi lisan bhanti-bhanti, ibu-ibu di Wakatobi juga menanamkan impian kepada anak-anaknya sehingga dapat dikatakan bahwa pementasan tradisi bhanti-bhanti merupakan media komunikasi kultural yang dapat dijadikan sebagai tempat menanamkan impian dan harapan kepada masyarakat Wakatobi -Buton di masa yang akan datang. Melalui tradisi lisan bhanti-bhanti, semua perbedaan akan dikomunikasikan tanpa harus menimbulkan ketersinggungan karena disampaikan dalam bentuk canda dan tawa. Namun, inti komunikasi dapat dipahami oleh kedua belah pihak.

\section{TRADISI LISAN BHANTI-BHANTI SEBAGAI MEDIA KOMUNIKASI MUDA-MUDI}

Selain menjadi ruang komunikasi antara anak dan ibunya, pementasan tradisi lisan bhanti-bhanti Wakatobi juga menjadi ruang komunikasi antara muda-mudi di Wakatobi. Sejak zaman Kesultanan Buton, masyarakat Wakatobi telah menggunakan pementasan bhanti-bhanti sebagai media untuk mengomunikasikan pikiran dan perasaan mereka. Dalam pementasan tradisi lisan bhanti-bhanti yang dilakukan oleh Wa Ina Ki'i dengan La Ode Kamaluddin, dikomunikasikan berbagai hasrat dan perasaan mereka melalui tradisi lisan bhantibhanti. Mereka mengungkapkan cinta mereka dan melalui pementasan itu juga mereka merespons perasaan cinta tersebut. Ungkapan cinta yang dianggap tabu dalam komunikasi biasa tetap diterima oleh masyarakat jika disampaikan dalam pementasan tradisi lisan bhanti-bhanti. Teks-teks yang mengarah ke hal-hal yang berbau porno pun justru ditanggapi dengan canda dan tawa. Wa Ina
Kii mengatakan bahwa "andaikan kita dengar pada kondisi yang biasa, kita wajib tersinggung, tetapi karena kita dengar dalam lantunan bhanti-bhanti, kita merasa bahagia" (wawancara dengan Wa Ina Ki'i tanggal 19 Februari 2012).

Dalam pementasan itu, La Ode Kamaluddin dan Wa Ina Kii saling menyindir (bhanti) untuk mengungkapkan perasaan mereka. Sebagai seorang laki-laki, La Ode Kamaluddin mengungkapkan perasaannya dengan bait sebagai berikut.

Patanta nggala nte Bentangkanlah walaupun hani'u hanya lenganmu

Ako te kokaule'asu Untuk tempat aku berpegangan

Mendengarkan sindiran tersebut kemudian Wa Ina Kii menjawab

$\begin{array}{ll}\begin{array}{l}\text { Na buku } \\ \text { nungkokaule'u }\end{array} & \text { Kuatnya kau memeluk } \\ \begin{array}{l}\text { Nungkoto'emo ngke } \\ \text { kutasu }\end{array} & \begin{array}{l}\text { Kau putuskan dengan } \\ \text { kutangku }\end{array}\end{array}$

Selanjutnya, La Ode Kamaluddin menjawab lagi dengan bait bhanti-bhanti berikut.

$\begin{array}{ll}\begin{array}{l}\text { Na buku } \\ \text { nubhangunturu'u }\end{array} & \begin{array}{l}\text { Kuatnya kau mengikut } \\ \text { angin }\end{array} \\ \begin{array}{l}\text { Nokoto ke sala } \\ \text { larosu }\end{array} & \begin{array}{l}\text { Sudah putus dengan } \\ \text { celana dalamku }\end{array}\end{array}$

Mendengarkan jawaban La Ode Kamaluddin seperti itu, Wa Ina Kii tertawa dan berkata, "kita berhenti dahulu, nanti kita sambung lagi, sudah terlalu jauh arah bhanti kita, kita berhenti dahulu, nanti kita sambung lagi". Maka, La Ode Kamaluddin menghentikan gambusnya, lalu mereka bercerita tentang hubungan laki-laki dan perempuan di dalam masyarakat Wakatobi yang penuh dengan kontrol sara. Masyarakat adat atau sara memiliki wewenang untuk mengontrol hubungan laki-laki dan perempuan. Melalui tradisi kabuenga atau ayunan, sara dapat mengontrol hubungan laki-laki dan perempuan yang sedang bertunangan.

Teks tradisi lisan bhanti-bhanti di atas sudah masuk dalam kategori ungkapan yang tabu atau 
pemali dalam budaya masyarakat Wakatobi, tetapi karena ini diungkapkan dalam pementasan tradisi bhanti-bhanti, maka itu dianggapnya sebagai sebuah canda dan hiburan. Dalam pementasan tersebut, masalah perasaan antara pelantun dapat diungkapkan sambil bercanda, dan bila pementasan tradisi lisan bhanti-bhanti dilakukan oleh muda-mudi, tradisi itu akan menjadi ruang pengungkapan cinta yang menarik karena melalui teks bhanti-bhanti seseorang dapat mengungkapkan pikiran dan perasaannya kepada salah seorang penonton tanpa harus membuat penonton itu tersinggung atau marah.

Beberapa konteks pementasan tradisi lisan bhanti-bhanti yang biasa digunakan untuk mengungkapkan pikiran dan perasaan cinta antara muda-mudi adalah dalam tradisi kabuenga dan hekomba'a. Dalam tradisi kabuenga (ayunan), tradisi lisan bhanti-bhanti menjadi media komunikasi bagi mereka yang saling jatuh cinta. Mereka akan mengungkapkan perasaan mereka melalui lantunan bhantibhanti. Cinta yang terlarang oleh adat pun dapat diungkapkan melalui teks bhanti-bhanti. Hal ini sebagaimana dilantunkan oleh La Mbongo dalam pementasannya di Waginogo tanggal 16 Oktober 2012 sebagai berikut.

\section{Kumala mou nte tuhasu \\ Aku akan mencintai walau saudaraku \\ La'a nohekombi na Nanti kampung melakukan togo ritual}

Teks di atas menunjukkan bahwa melalui pementasan tradisi lisan bhanti-bhanti seorang laki-laki dapat mengungkapkan cintanya. Ia mengabaikan berbagai larangan adat untuk diadakannya pertunangan atau perkawinan dengan ina sepupu dan ama sepupu. Ia justru menantang adat untuk melakukan ritual penolakan bala atas pertunangan itu. Dalam masyarakat Wakatobi memiliki kepercayaan bahwa hubungan antarama sepupu (kemenakan dengan paman) dan ina sepupu (kemenakan dengan bibi) akan berdampak pada bencana berupa kemarau dan penyakit. Mereka percaya bahwa jika di dalam masyarakat memiliki pertunangan yang dekat, akan terjadi bencana alam dan penyakit. Dalam kondisi ini, sara (pihak adat) akan selalu memeriksa dan mengobati hal tersebut dalam tradisi kabuenga (ayunan) dan mangani'a nu uwe (sesajian pada air). Melalui momen itulah, pihak sara melakukan ritual untuk menolak bala atau dampak dari pertunangan itu. Namun, di dalam teks bhantibhanti, La Mbongo mengungkapkan cintanya dengan mencoba menentang adat. Mendegarkan lantunan seperti itu, pihak adat (sara) akan melakukan ritual dan biasanya akan menjawab dengan teks lara to padha mobasamo/ "kalau kita sudah sama-sama dewasa" /mou te tuhanto to meri/ "walaupun saudara kita harus waspada". Ini menunjukkan ruang komunikasi kultural yang menanamkan nilai-nilai budaya dalam masyarakat Wakatobi, yaitu pihak adat memberikan perhatian kepada pihak keluarga dan gadis-gadis atas batasbatas pergaulan di dalam masyarakat.

Di samping pengungkapan cinta melalui tradisi lisan bhanti-bhanti yang dilaksanakan pada tradisi kabuenga, masyarakat Wakatobi juga mengenal tradisi hekomba'a. Tradisi hekomba'a merupakan tradisi masyarakat Wakatobi, terutama masyarakat Wangi-Wangi dimana kaum perempuan mengumpulkan kayu dan membuat api unggun di malam hari (wawancara dengan La Wole-Wole tanggal 12 Januari 2013). Di saat api unggun sudah menyala, mereka melantunkan tradisi bhanti-bhanti. Lakilaki dan perempuan duduk berhadapan diantarai oleh api unggun. Mereka akan saling melempar bhanti atau pantun sehingga jika seorang laki-laki mempunyai cinta pada perempuan, maka akan leluasa mengungkapkan cintanya melalui teks bhanti-bhanti. Persahabatan antara perempuan dan laki-laki dalam konteks hekomba'a, mereka istilahkan dengan kene atau saudara (Wawancara dengan Wa Ode Bulalu tanggal 06 Oktober 2012). Pada beberapa dekade yang lalu, laki-laki dan perempuan di Wakatobi banyak mengenal cinta dalam kegiatan tradisi ini hekomba'a seperti ini. Mereka memiliki kesempatan untuk mengungkapkan cinta mereka. 
Dalam konteks yang lain, pementasan tradisi lisan bhanti-bhanti pernah dilakukan di pantai Toronipa Kendari oleh beberapa mahasiswa asal Wakatobi. Saat melakukan tamasya di pantai itu, mereka melantunkan bhanti-bhanti, dan pada saat itu seorang mahasiswa mengungkapkan perasaannya pada seorang temannya dengan teks bhanti-bhanti berikut.

$\begin{array}{lll}\begin{array}{l}\text { E na leu nuromu- } \\ \text { romunto }\end{array} & \begin{array}{l}\text { Bagusnya } \\ \text { berkumpul }\end{array} & \text { kita } \\ \begin{array}{l}\text { E ara pakamo nta } \\ \text { moga'a }\end{array} & \begin{array}{l}\text { Andaikan kita tidak } \\ \text { berpisah }\end{array} \\ \begin{array}{l}\text { E mou tokoruo } \\ \text { toromu }\end{array} & \begin{array}{l}\text { Walaupun banyak kita } \\ \text { berkumpul }\end{array} \\ \begin{array}{l}\text { E buntu Wa Nina } \\ \text { ngkupoilu }\end{array} & \begin{array}{l}\text { Hanya Wa Nina yang } \\ \text { kusuka }\end{array}\end{array}$

Mendengarkan lantunan teks bhantibhanti seperti itu, perempuan yang bernama Wa Nina tersipu dan raut wajahnya memerah. Melihat apa yang terjadi, seorang pelantun lain menjawab dengan teks bhanti-bhanti lara te sidha ngkelaro' $u /$ 'kalau memang dengan hatimu' / tumpu'e na manuana'u/ 'suruhlah orang tuamu'. Banyak laki-laki dan perempuan Wakatobi yang mengungkapkan perasaan mereka melalui tradisi bhanti-bhanti. Kalau dalam konteks biasa mereka malu, maka melalui lantunan bhanti-bhanti mereka bebas mengungkapkan perasaan mereka. Mendengarkan sindiran seperti itu, ternyata mahasiswi yang disindir tersebut mengambil dengan hati dan akhirnya ia memberitahu orang tuanya, bahwa ada laki-laki yang mencintainya.

Dalam sejarah pobhanti di Wakatobi, acara pobhanti tidak selamanya menjadi ruang komunikasi yang positif, tetapi juga dapat menjadi ruang komunikasi yang negatif. Hal ini dapat dilihat dari pengalaman masyarakat Wakatobi atas suatu peristiwa pobhanti'a yang terjadi di kampung Po'o Kambua beberapa tahun silam. Acara tersebut melahirkan kesalahpahaman hanya karena kerasnya sindiran yang diungkapkan oleh para pelantun yang berasal dari Bhira Wandoka. Mereka melantunkan teks bhanti-bhanti sebagai berikut.
E Te po'o bula dhi Mangga bula di Bhaobhe Bhaobhe

E no mota'a dhi Masak karena di remaslende-lende remas

Mendengarkan bhanti seperti itu, masyarakat Po'o Kambua tersinggung karena mereka disindir bahwa gadis-gadis putih yang ada di kampung mereka, cepat dewasa karena buah dadanya selalu diremas-remas. Mendengarkan itu, mereka langsung membalas dengan teks sebagai berikut.

\section{E te loka mepanda di Pisang pendek di Bhira Bhira

E bungku'e te $\begin{aligned} & \text { Dibungkukkan oleh } \\ & \text { jantungnya }\end{aligned}$

Mendengarkan jawaban itu, orang-orang Bhira pun tersinggung karena mereka juga disindir bahwa gadis-gadis di Bhira dibungkukkan oleh buah dadanya yang besar. Dua teks bhanti-bhanti yang dilantunkan saat acara pobhanti di atas telah memberikan komunikasi yang tidak harmonis antara kedua tim. Bahkan, walaupun sudah berulang kali teks penetralisir dilantunkan, kedua belah pihak masih tetap tersinggung. Jika terjadi kasus seperti itu, selalu ada teks penetralisir dalam tradisi bhanti-bhanti atau pobhanti'a sebagai berikut.

\section{E Te mia sumeki te Orang yang tersinggung bhanti dengan bhanti \\ $E$ te atumo na mia Sudah itu orang jahat dha'o}

Dengan demikian, sebagai ruang komunikasi kultural, tradisi lisan bhanti-bhanti memiliki peluang untuk menciptakan ruang dialog yang baik, tetapi di sisi yang lain, jika para pelantun tidak hati-hati, tidak menutup kemungkinan untuk terjadinya sumber masalah. Namun, jika terjadi ketidakharmonisan dalam pementasan tradisi lisan bhanti-bhanti (pobhanti) seperti yang terjadi dalam konteks di atas, akan turun tangan tokoh-tokoh masyarakat untuk memperbaiki kondisi masyarakat seperti itu, dan biasanya juga digunakan dalam bentuk pementasan tradisi lisan bhanti-bhanti berikutnya. 


\section{BHANTI-BHANTI SEBAGAI KOMUNIKASI ANTARKAMPUNG}

Dalam kehidupan masyarakat Wakatobi dewasa ini, persaingan antarkampung pun sering terjadi. Banyak perselisihan yang kecil, tetapi karena mengatasnamakan kampung, konflik kecil itu dapat berkembang menjadi konflik terbuka sehingga keberadaan tradisi lisan bhanti-bhanti diharapkan dapat menjadi media komunikasi yang efektif dalam membangun dialog antarkampung dalam masyarakat Wakatobi dewasa ini. Untuk itu, pementasan tradisi lisan bhanti-bhanti sejak dahulu memegang peran penting, baik untuk mengingat peristiwa masa lalu maupun untuk memecahkan berbagai persoalan antarkampung di dalam masyarakat Wakatobi.

Beberapa persoalan dalam masyarakat Wakatobi saat ini biasanya selalu menggunakan ingatan kolektif mereka sebagai acuan dalam pemecahannya, misalnya persoalan batas wilayah antara Mandati dan Wanse yang selama ini menjadi sumber konflik sosial yang ada di dalam masyarakat Wangi-Wangi diabadikan dalam teks bhanti-bhanti berikut.

Te Wansemo te $\begin{aligned} & \text { Baik Wanse maupun } \\ & \text { Mandatimo }\end{aligned}$
$\begin{aligned} & \text { Mhi endapo } \\ & \text { nakasilapa }\end{aligned}$

Dalam memecahkan masalah batas wilayah antara kadhia atau desa tersebut, masyarakat Mandati dan Wanse akhirnya mengacu pada teks bhanti-bhanti di atas. H. La Morunga mengatakan bahwa batas Wanse dengan Mandati terletak di Endapo (wawancara dengan H. la Morunga pada tanggal 17 Februari 2012). Oleh karena itu dalam keberadaannya sebagai nyanyian rakyat, bhanti-bhanti dapat menjadi ruang komunikasi kultural dan sekaligus menjadi ruang ingatan kolektif mereka sehingga dapat dipahami oleh satu generasi ke generasi berikutnya.

Di samping itu, untuk menyelaraskan kehidupan masyarakat antar pulau di Wakatobi mereka juga mengenal teks bhanti-bhanti berikut Imou nopoga'a na mbajal 'walaupun badan berpisah' /topoasa di ngaga randa/ 'kita bersatu dalam rasa'. Untuk menggambarkan kebersamaannya, pelantun bhanti-bhanti /te Wakatobi hatowala/ 'Wakatobi empat segi' / awana wala nu orungu/ 'seperti empat belahan badan'. Namun, keragaman etnis yang mendiami kampung-kampung di Wakatobi juga tidak terlepas dari sindiran bhanti-bhanti. Dalam suatu pementasan bhanti-bhanti La Mbongo mengungkapkan bahwa /ka'asi na tanga ngkaledupa/ 'kasihan bahasa Kaledupa' lte kiwolu tengkiwo-kiwo/ 'kerang kowolu (cymbiola imperialis) disebut merayap-rayap'. Selanjutnya, ia juga mengatakan bahwa /suruno kukiwo wa tuha/ 'mengapa saya merayap saudariku', /topokai dhi ngaga randa/ 'karena ada keterkaitan hati'.

Dalam pementasan yang lain, tradisi lisan bhanti-bhanti mampu menjembatani masalah anak muda antarkampung di Wakatobi. Dalam sebuah pesta (joget) banyak menimbulkan perkelahian antaranak muda yang sering kali mengatasnamakan kampung, dan jika ini terjadi dalam masyarakat Wakatobi di masa lalu, penyelesaiannya adalah di saat pobhanti'a. Beberapa teks bhanti-bhanti yang dapat digunakan untuk menyelesaikan masalah anak muda tersebut adalah lara kosala wilangka la tuha/ 'kalau kami sudah salah langkah saudaraku' / ka'asi maafu kokami/ 'kasihan maafkanlah kami'. Mendengarkan ucapan mohon maaf seperti itu, pihak kampung lain, akan mengungkapkan teks bhanti-bhanti berikut. /mai topadha ntarimane/ 'mari kita sama-sama terima' Ina kobhe kene ngkasalaha/ 'kebenaran dan kesalahan'. Biasanya, ketika kedua belah pihak saling menerima kebenaran dan kesalahan seperti itu, akan dibangun dialog yang lebih baik lagi melalui teksteks bhanti-bhanti berikutnya sehingga di zaman dahulu, pertengkaran antarkampung tersebut dapat dihindari.

Dengan demikian, beberapa permasalahan antarkampung di dalam masyarakat Wakatobi dahulu dapat diselesaikan melalui pementasan tradisi lisan bhanti-bhanti. Konteks-konteks seperti hekomba'a dan mangani'a nu kabuenga 
dapat dijadikan sebagai ruang-ruang pementasan tradisi lisan bhanti-bhanti yang dapat menyelesaikan berbagai persoalan antarkampung dalam masyarakat Wakatobi. Berbagai persoalan masyarakat dapat diselesaikan melalui dialog yang dilantunkan dalam berbagai pementasan tradisi lisan bhanti-bhanti sehingga di masa depan pementasan tradisi lisan bhanti-bhanti dapat dimanfaatkan dalam proses dialog antara kampung di Wakatobi, baik yang menyangkut penyelesaian masalah maupun dalam proses membangun mimpi bersama.

\section{BHANTI-BHANTI SEBAGAI MEDIA KOMUNIKASI ANTARA RAKYAT DAN PEMERINTAH}

Sebagai tradisi lisan, bhanti-bhanti telah lama menjadi media komunikasi antara rakyat dan pemerintahnya. Sejak zaman Kesultanan Buton, beberapa kabhanti atau bhanti-bhanti yang digunakan untuk melakukan kritik kepada pemerintah adalah kabhanti yang dikarang Syeh Haji Abdul Ganiu. Dalam katalog naskah Buton (Ikram, 2001), kabhanti Anjonga Yinda Malusa merupakan salah satu naskah kabhanti yang populer dalam masyarakat Buton dan sampai saat ini masih tersimpan di dalam koleksi Abdul Mulku Zahari. Dalam kabhanti tersebut, khususnya bait 130-132 Haji Abdul Ganiu memberikan kritik kepada pemerintah kesultanan Buton bahwa

$\begin{array}{ll}\begin{array}{l}\text { Ee lalaki mokenina } \\ \text { kapooli }\end{array} & \begin{array}{l}\text { Wahai bangsawan } \\ \text { pemegang kekuasaan }\end{array} \\ \begin{array}{l}\text { Maeya mpuu neinda } \\ \text { beya membali }\end{array} & \text { Sangatlah malu jika tidak } \\ \text { jeydi } \\ \begin{array}{l}\text { Nari yitu } \\ \text { Pakorouya (siymbau) } \\ \text { onimu yitu }\end{array} & \begin{array}{l}\text { Kalau berjanji dengan } \\ \text { orang banyak itu }\end{array} \\ \begin{array}{l}\text { Totuunamo aneinda } \\ \text { membali }\end{array} & \text { itu } \\ \text { Sebenarnya kalau tidak } \\ \text { Sowuniko inda beya } & \text { Tadi } \\ \text { Sabutunamo manga } & \text { menghadapmu tidak mesti } \\ \text { soya paramuntu } & \begin{array}{l}\text { Begitulah mereka dengan } \\ \text { membuat isu }\end{array}\end{array}$

$\begin{array}{ll}\begin{array}{l}\text { Hengga kawana } \\ \text { idaga atula-tula }\end{array} & \begin{array}{l}\text { Sampai pada orang asing } \\ \text { bercerita }\end{array} \\ \begin{array}{l}\text { Akolosamo ingkoo } \\ \text { utorangomo }\end{array} & \begin{array}{l}\text { Menjadikan engkau } \\ \text { dapat didengarkan }\end{array} \\ \begin{array}{l}\text { Upewulimo sabara } \\ \text { anguna lipu }\end{array} & \begin{array}{l}\text { Berdusta pada penjuru } \\ \text { negeri }\end{array} \\ \begin{array}{l}\text { Hengga kawana } \\ \text { anamu teyopuamu }\end{array} & \begin{array}{l}\text { Hinga sampai anak } \\ \text { cucumu }\end{array} \\ \text { A m e m b a l i mo } & \text { Akan menjadi luka di } \\ \text { kabelana talingana } & \text { telinganya }\end{array}$

Melalui teks kabhanti di atas, Haji Abdul Ganiu (seorang sufi dan sastrawan Buton abad 19) mengingatkan agar seorang pemimpin itu harus menepati janjinya kepada rakyat, karena jika tidak, maka akan tersebar isu tentang kebohongan itu hingga ke anak cucu. Dia akan diceritakan oleh semua orang dan anak cucunya pun akan malu akibat perbuatannya. Teks kabhanti Anjonga Yinda Malusa menjadi teks sastra yang banyak dipentaskan oleh masyarakat Wakatobi Buton dari dahulu sampai sekarang.

Kemudian dalam usahanya untuk memperbaiki masyarakatnya, Sultan La Buke menulis naskah kabhanti Kaluku Panda Atuwu Incana Dempa (kelapa pendek yang tumbuh di batu cadas) untuk memperbaiki sifat dan keturunan masyarakat Buton yang telah banyak menyimpang terutama dalam hal seks. Masyarakat Buton mendapatkan pelajaran tentang seks melalui teks bhanti-bhanti yang dikarang oleh sultan mereka. Teks itu kemudian dipentaskan di berbagai tempat sehingga masyarakat dapat mengetahui tata cara seks yang baik sehingga dapat menghasilkan generasi Buton yang berkualitas (Udu, 2010:258).

Dalam konteks Wakatobi dewasa ini, sikap pejabat yang sering mengumbar janji saat kampanye dan melupakan janjinya di saat mereka telah berkuasa, kebanyakan mereka mengingkari janjinya kepada masyarakat, dan mereka hanya fokus pada upaya untuk memperkaya diri sendiri dan keluarga. Sehubungan dengan bagaimana penguasa yang tidak adil tersebut, Haji Abdul Ganiu dalam kabhanti Anjonga Yinda Malusa bait 128-129 menasihati para penguasa sebagai berikut. 


$\begin{array}{ll}\begin{array}{l}\text { Ee lalaki mokenina } \\ \text { kapooli }\end{array} & \begin{array}{l}\text { Wahai bangsawan } \\ \text { pemegang kekuasaan }\end{array} \\ \begin{array}{l}\text { Miya kidina kumalua } \\ \text { runaiya }\end{array} & \begin{array}{l}\text { Orang kecil sayangi } \\ \text { dengan kasih }\end{array} \\ \begin{array}{l}\text { Alaa keya panata } \\ \text { mina iopu }\end{array} & \begin{array}{l}\text { Ambilkan mistar dari } \\ \text { Tuhan }\end{array} \\ \begin{array}{l}\text { Nunua keya kabori } \\ \text { mina baana }\end{array} & \begin{array}{l}\text { Telusurkan dengan garis } \\ \text { dari awalnya }\end{array} \\ \begin{array}{l}\text { Taoyakana atorango } \\ \text { kalapemu }\end{array} & \begin{array}{l}\text { Sebabnya terdengar/ } \\ \text { tersiar kebaikanmu }\end{array} \\ \begin{array}{l}\text { Sabaraaka anguna } \\ \text { lipu marido }\end{array} & \begin{array}{l}\text { Segala penjuru negeri } \\ \text { yang jauh }\end{array} \\ \begin{array}{l}\text { Rampa sababu } \\ \text { polelena miya bari }\end{array} & \begin{array}{l}\text { Sebab pemberitaan } \\ \text { banyak orang }\end{array} \\ & \text { orena }\end{array}$

Teks bhanti-bhanti di atas menunjukkan bahwa melalui teks tersebut, Haji Abdul Ganiu melakukan kritik atau menasihati penguasa agar mereka berhati-hati dalam menjalankan pemerintahan. Ia juga mengkritik penguasa agar penguasa harus adil dan mengasihi rakyatnya. Penguasa harus menggunakan konsep sunatullah yang mengabdi kepada rasa kemanusiaan dalam mengatur masyarakat. Rasa keadilan, kasih sayang, dan cinta harus dijadikan sebagai landasan dalam kepemimpinannya.

Dalam pementasan tradisi lisan bhanti-bhanti yang dilaksanakan di kantor Dinas Pariwisata Kabupaten Wakatobi pada tanggal 19 Februari 2012, La Ode Kamaluddin menyikapi sikap pemimpin yang tidak adil tersebut dengan teks bhanti-bhanti berikut.

$\begin{array}{ll}\begin{array}{l}\text { Patoro La bhonto } \\ \text { patoro }\end{array} & \begin{array}{l}\text { Bersikap adillah hai } \\ \text { penguasa }\end{array} \\ \begin{array}{l}\text { Te dhunia no lingka- } \\ \text { lingkamo }\end{array} & \begin{array}{l}\text { Dunia sudah mulai } \\ \text { miring }\end{array} \\ \begin{array}{l}\text { Suru no lingka na } \\ \text { dhunia }\end{array} & \begin{array}{l}\text { Mengapa dunia menjadi } \\ \text { miring }\end{array} \\ \begin{array}{l}\text { Te hale pake } \\ \text { nsagau'u }\end{array} & \begin{array}{l}\text { Karena kau bertindak } \\ \text { sekehendakmu }\end{array}\end{array}$

Teks-teks di atas merupakan refleksi seorang pelantun atas sikap dan tanggapan masyarakat Wakatobi atas pelaksanaan pemerintahan di kabupaten Wakatobi yang terlalu berpihak pada golongan atau partainya. Ini merupakan bentuk protes (tapa) atau kritik yang dilakukan oleh masyarakat terhadap pemerintahnya. La Ode Kamaluddin mengingatkan agar pemerintah harus bersikap adil karena dunia sudah miring. Ia juga mengatakan penyebab dunia miring karena sikap penguasa yang berbuat sekehendak hatinya.

Kemudian, untuk menjelaskan kritik itu penting, La Ode Kamaluddin melantunkan teks / Tapa wa ina nteadari/ 'kritik ibu adalah pelajaran' /te sinta te aka sinea/ 'sedangkan kasih sayang itu hanyalah mainan'. Dengan teks bhanti-bhanti di atas, memungkinkan untuk terbukanya kritik sosial dalam tradisi bhanti-bhanti dalam masyarakat Wakatobi.

Kritik-kritik sosial yang dilantunkan dalam pementasan tradisi lisan bhanti-bhanti tersebut kemudiaan ditanggapi oleh masyarakat adat (sara) dengan memperbaiki diri dan kepemimpinannya. Mereka akan mengoreksi kesalahan mereka dalam pemerintahan. Mereka akan merespons teks bhanti-bhanti tersebut dengan langkah nyata. Kepercayaan masyarakat dapat dikembalikan dan masyarakat dapat mendukung pemerintahan, mereka membayar pajak dan menghormati pemimpin. Sebaliknya, jika penguasa atau pemerintah tidak merespon pesan-pesan tersebut, masyarakat akan mempergunjingkan kesalahan pemerintah dan membuat perlawanan pada kebijakan-kebijakan pemerintah yang tidak adil tersebut.

Mendapatkan berbagai kritikan dari masyarakat seperti itu, biasanya masyarakat adat atau sara akan menjawab bahwa /nopake toumpa na mia/ 'orang berbuat seperti apa' / no awane na ngkobheal 'mereka menemukan kebenaran'. Ketika itu dijawab, masyarakat akan menjawab /toawane na ngkakobhea/ 'kita temukan kebenaran' /tohetotone nte namisi/ 'kompasnya adalah rasa kemanusiaan'. Dialog di atas menunjukkan bahwa pemerintah (masyarakat adat) dengan masyarakat Wakatobi di zaman dahulu selalu melakukan dialog dalam menjalankan pemerintahan. 
Persoalan-persoalan yang tidak dapat dikomunikasikan melalui komunikasi biasa, akan mudah dilakukan melalui pementasan tradisi lisan bhanti-bhanti karena dalam pementasan tersebut pelantun dan pendengar akan bebas mengekspresikan pikiran dan perasaanya karena tidak akan satu pun yang hadir di situ dapat tersinggung. Masyarakat dan pemerintah akan memanfaatkan pementasan tradisi lisan bhantibhanti sebagai media untuk menyampaikan berbagai persoalan yang ada di dalam masyarakat.

Dengan demikian, dapat dikatakan bahwa pementasan tradisi lisan bhanti-bhanti dalam masyarakat Wakatobi dapat dijadikan sebagai media komunikasi kultural antara masyarakat dan pemerintah (sara). Berbagai permasalahan pemerintah Wakatobi dengan lembaga adat dan masyarakat hendaknya menggunakan media komunikasi kultural sehingga mereka bisa membuka diri, tanpa harus saling memaki seperti terjadi dalam berbagai model komunikasi modern yang dilakukan oleh para demonstran di jalanan. Melalui komunikasi kultural yang dilakukan dalam pementasan tradisi lisan bhanti-bhanti ini, diharapkan pembangunan Wakatobi dapat lebih lancar, dan pelaksanaan pemerintahan dapat lebih adil dan dipahami oleh masyarakat. Hal ini karena dalam pementasan tradisi lisan bhanti-bhanti tidak ada jarak antara berbagai kepentingan yang ada.

\section{SIMPULAN}

Berdasarkan pembahasan di atas, dapat disimpulkan bahwa pementasan tradisi lisan bhanti-bhanti dapat menjadi media komuniksi kultural dalam masyarakat Wakatobi karena tradisi lisan bhanti-bhanti dapat menjembatani berbagai kepentingan, baik untuk kalangan orang tua dan anak, untuk kalangan muda-mudi, kalangan sara, dengan masyarakat, maupun komunikasi kultural antara kampung dengan kampung. Sebagai tradisi lisan yang tumbuh dan berkembang dalam masyarakat Wakatobi, tradisi lisan bhantibhanti dapat dijadikan sebagai salah satu ruang komunikasi kultural dalam menyampaikan berbagai program pemerintah daerah mengingat tradisi lisan bhanti-bhanti masih tetap menjadi ruang hiburan masyarakat yang masih disukai dan berkembang dalam masyarakat Wakatobi.

\section{DAFTAR RUJUKAN}

Moradewun, Adejunmobi. (2011). "Revenge of the Spoken Word?: Writing, Performance, and New Media in Urban West Africa" Oral Tradition, Vol. 26. No. 1 (2011), hlm. 3-26.

Albom, Mitch. (2006). Selasa Bersama Morrie. Diterjemahkan oleh Alex Tri Kontjono Widodo. Jakarta: PT. Gramedia Pustaka Utama.

Anceaux, J.C. (1988). The Wolio Language: Outline of Grammatical Description and Texts. Foris Publications: Holand.

Boyer, Pascal. (1990). Tradition as Truth and Communication: A Cognitive Description of Traditional Discourse. New York and Melbourne: Cambridge University Press.

Esten, Mursal. (1999). Desentralisasi Kebudayaan. Bandung: Angkasa.

Fakih, Mansour. (2003). Runtuhnya Teori Pembangunan dan Globalisasi. Yogyakarta: Insist Prees bekerja sama dengan Pustaka Pelajar.

Fine, Elizabeth. C. (1984). The Folklore Text. Bloomington and Indianapolis: Indiana University Press.

Finnegan, R. (1977). Oral Poetry: Its Nature, Significance and Social Context. Cambridge: Cambridge University Press.

(1978). Oral Literature in Africa. Nairobi, London: Oxford University Press.

(1992). Oral Traditions and The Verbal Arts: A Guide to Research Practices. London and New York: Routledge.

Hamid, Abd. Rahman. (2010). Spirit Bahari Orang Buton. Makassar: Raihan Intermedia.

Ikram, Achadiati dkk. (2001). Katalog Naskah Buton: Koleksi Abdul Mulku Zahari. Jakarta: Manassa (Masyarakat Pernaskahan Nusantara) dan Yayasan Obor Indonesia.

La Niampe. (1998). "Kabhanti Bula Malino: Kajian Filologi Sastra Wolio Klasik". Universitas 
Padjadjaran: Tesis Program Pascasarjana, Bandung.

(2010). "La Ode Muhammad Idrus Qaimuddin Sastrawan Sufi Ternama di Buton Abad XIX" dalam Jurnal Humaniora, Vol. 22 Nomor 3 tahun 2010, Hlm. 250-265.

Nsaha, La Ode, Tamburaka, dan Asis. (1978/1979). Aneka Budaya Sulawesi Tenggara. Kendari: Proyek Penggalian Nilai-Nilai Budaya Sulawesi Tenggara.

Rabani, La Ode. (1997). "Migrasi dan Perkembangan Sosial Ekonomi Masyarakat Kepulauan Tukang Besi Kabupaten Buton 1961-1987’. Yogyakarta: Skripsi Fakultas Sastra Universitas Gajah Mada.

Rusdin, Ali. (2002). Kaluku Panda: Telaah Filologis Naskah Wolio. Bandung: Tesis Pascasarjana Universitas Padjajaran.

Schoorl, Pim. (2003). Masyarakat, Sejarah dan Budaya Buton. Jakarta: Djambatan, KITLV.

Suyitno, Imam. (2006). “Komunikasi Antaretnik dalam Masyarakat Tutur Diglosik: Kajian Etnografi Komunikasi Etnik Using" dalam Humaniora Volume 18 No. 3 Oktober 2006, hlm. 263-270.

Taalami, La Ode. (2008). Mengenal Kebudayaan Wakatobi. Jakarta: Granada.

Udu, Hamiruddin. (2006). "Metafor dalam Kabhanti Pengantar Tidur”. Yogyakarta: FIB UGM. . (2007). "Konsep Seks Masyarakat Buton" dalam Naskah Buton Naskah Dunia: Prosiding
Seminar Internasional IX Pernaskahan Nusantara di Kota Bau-Bau.” Editor: M. Yusran Darmawan. Bau-Bau: Respect- (257-272)

(2010). Perempuan dalam Kabhanti: Tinjauan Sosiofeminis. Yogyakarta: Penerbit Diandra.

. (2012). "Pengembangan Pariwisata dan Hilangnya Tanah-tanah Sara di Wakatobi: Kajian atas Perlawanan Masyarakat Adat" (Makalah International Conference \& Summer School on Indonesian Studies, Fakultas Ilmu Pengetahuan Budaya Universitas Indonesia yang dilaksanakan di Sanur Bali tanggal 9 -10 Februari 2012).

Zuhdi, Susanto. (1999). Labu Wana Labu Rope: Sejarah Buton Abad XVII-XVIII. Jakarta: Disertasi Program Pascasarjana Universitas Indonesia.

. (2012). "Perahu yang Berlayar di Antara Karang-Karang Kesultanan Butuni” dalam Negeri Seribu Benteng: Lima Abad Dinamika di Kota Bau-Bau. Editor: M. Yusran Darmawan dan Muh. Mu'min F. Bau-Bau: Respect (vii-xxvi).

\section{Laman}

http://jatengonline.com/26/01/2013/dalam-tatarankomunikasi-kultural.html. Diak-ses pada tanggal 24 Januari 2014.

\section{Sumber Data}

Naskah Kabhanti Anjonga Yinda Malusa karya Haji Abdul Ganiu. Koleksi Abdul Mulku Zahari, kode Naskah 302 